\title{
Peripheral neuropathy associated with primary Sjögren's syndrome
}

Franco Gemignani, Adriana Marbini, Giovanni Pavesi, Stefano Di Vittorio, Paolo Manganelli, Giovanna Cenacchi, Domenico Mancia

\begin{abstract}
Clinical and electrophysiological signs of peripheral neuropathy were found in $\mathbf{1 0}$ of 46 patients $(21 \cdot 7 \%)$ with primary Sjögren's syndrome, symmetric polyneuropathy in seven (mainly sensory in five, mainly autonomic in two), sensory neuronopathy in two patients, and mononeuropathy multiplex in one patient. Peripheral neuropathy was the presenting manifestation in five patients $(10.9 \%)$. Onset of the disease after 50 years was significantly more common in the polyneuropathy group (six of seven) than in non-neuropathic patients with primary Sjögren's syndrome (14 of 36; $p=0 \cdot 034)$. No other difference in clinical or laboratory variables between neuropathic and non-neuropathic patients with primary Sjogren's syndrome was found. Neurophysiological study showed variable findings predominantly suggesting an axonopathy. Nerve biopsy showed moderate remyelination and regeneration in four patients, and fibre loss, mainly of large size, in three. Necrotising vasculitis was not seen but alterations of the endoneurial microvessels were prominent.
\end{abstract}

(F Neurol Neurosurg Psychiatry 1994;57:983-986)

Institute of Neurology, University of Parma,

Parma, Italy

F Gemignani

A Marbini

G Pavesi

$S$ Di Vittorio

D Mancia

Rheumatic Disease

Unit, University of

Parma, Parma, Italy

P Manganelli

Institute of Electron

Microscopy,

University of Bologna

Bologna, Italy

G Cenacchi

Correspondence to:

Dr Franco Gemignani,

Istituto di Neurologia,

Università di Parma, via del

Quartiere, 4 I-43100 Parma, Italy.

Received 23 November 1993 and in revised form

7 February 1994.

Accepted 16 February 1994
Therefore, the vasculitic pathogenesis ad vanced by some authors ${ }^{38}$ has to be critically evaluated in the light of the criteria for patients' selection. The aim of the present study was to assess the prevalence of clinically significant peripheral neuropathy and its range in a series of patients with well characterised primary Sjögren's syndrome, and to evaluate factors possibly related to its occurrence.

Patients and methods

Forty six consecutive patients (43 women, three men) with primary Sjögren's syndrome were evaluated for symptoms and signs of peripheral neuropathy, and submitted to neurophysiological investigation according to previously reported methods ${ }^{15}$ when clinical examination suggested peripheral neuropathy.

The diagnosis was made according to the Copenhagen criteria ${ }^{14}$ with minor modifications, when at least two out of four criteria were met for both xerophthalmia (subjective complaint of dry eyes, abnormal Schirmer test, abnormal break up time, positive rosebengal or fluorescein staining) and xerostomia (subjective complaint of dry mouth, history of parotid enlargement, abnormal salivary gland scintigraphy or sialography, positive lower lip biopsy showing focal sialoadenitis with more than one lymphocyte focus per $4 \mathrm{~mm}^{2}$, according to Greenspan et al. ${ }^{16}$ Primary Sjögren's syndrome was diagnosed in the absence of any other autoimmune rheumatic disease, sarcoidosis, lymphoma, and other malignancies, and of medications known to reduce secretions. Patients with diabetes, cryoglobulinaemia, alcoholism, and other conditions possibly causing peripheral neuropathy were also excluded. Clinical and laboratory variables (including immunoglobulin, latex test for IgM rheumatoid factor, C3 and C4, antinuclear antibody, antiparietal cells, antimitochondria, antismooth muscle, antithyroid, anti-Ro and anti-La antibodies) of neuropathic patients were analysed with regard to their possible relevance for the pathogenesis of peripheral neuropathy compared with the patients without peripheral neuropathy as a control group. Fischer's exact test was used for statistical comparison, and $p<0.05$ was considered significant.

Sural nerve biopsy was performed on seven patients with peripheral neuropathy (five 
Peripheral neuropathy and primary Sjögren's syndrome: patient data

\begin{tabular}{|c|c|c|c|c|}
\hline $\begin{array}{l}\text { Patient No } \\
\text { Sex (age) }\end{array}$ & $\begin{array}{l}\text { Type of } \\
\text { neuropathy }\end{array}$ & $\begin{array}{l}\text { Main neuropathic } \\
\text { symptoms and signs }\end{array}$ & $\begin{array}{l}\text { Onset: } \\
\text { age and symptoms }\end{array}$ & $\begin{array}{l}\text { Immunological } \\
\text { abnormalities }\end{array}$ \\
\hline $\mathrm{F}^{1^{\star}}(56)$ & $\begin{array}{l}\text { Sensory } \\
\text { polyneuropathy }\end{array}$ & $\begin{array}{l}\text { Numbness in the legs. } \\
\text { Distal sensory loss, } \\
\text { absent ankle jerks }\end{array}$ & $\begin{array}{l}52 \\
\text { Sicca }\end{array}$ & $\begin{array}{l}\text { RF + ANA } 1 / 20 \\
\text { IgA } 5 \cdot 4 \mathrm{~g} / 1\end{array}$ \\
\hline $\mathrm{F}^{2}(74)$ & $\begin{array}{l}\text { Sensory } \\
\text { polyneuropathy }\end{array}$ & $\begin{array}{l}\text { Moderate sensory ataxia. } \\
\text { Distal loss of touch sensation }\end{array}$ & $\begin{array}{l}73 \\
\text { Weight loss, sicca }\end{array}$ & $\begin{array}{l}\mathrm{C} 4=0.09 \mathrm{~g} / 1 \\
\mathrm{IgG} 22.8 \mathrm{~g} / 1 \\
\text { ESR } 30 \text { ANA } 1 / 80 \\
\text { antithyroid ab + }\end{array}$ \\
\hline$F^{3}(66)$ & $\begin{array}{l}\text { Sensory } \\
\text { polyneuropathy }\end{array}$ & $\begin{array}{l}\text { Painful legs and moving toes, } \\
\text { restless legs. } \\
\text { Distal sensory loss, absent } \\
\text { ankle jerks }\end{array}$ & $\begin{array}{l}63 \\
\text { Sicca, dysaesthesias }\end{array}$ & $\begin{array}{l}\mathrm{C} 4=0.03 \mathrm{~g} / 1 \\
\text { ESR 24, RF }+ \\
\text { antithyroid ab }+\end{array}$ \\
\hline$\stackrel{4}{M}(68)$ & $\begin{array}{l}\text { Mainly sensory } \\
\text { polyneuropathy }\end{array}$ & $\begin{array}{l}\text { Fatigue. } \\
\text { Distal impairment of deep } \\
\text { sensation }\end{array}$ & $\begin{array}{l}60 \\
\text { Fatigue }\end{array}$ & $\begin{array}{l}\mathrm{C} 4=1.9 \mathrm{~g} / 1 \\
\mathrm{IgG} 24.9 \mathrm{~g} / 1 \\
\text { anti-parietal cells ab } 1 / 80\end{array}$ \\
\hline $\mathrm{F}^{5}(76)$ & $\begin{array}{l}\text { Mainly sensory } \\
\text { polyneuropathy }\end{array}$ & $\begin{array}{l}\text { Distal weakness and pain in } \\
\text { the legs, restless legs. } \\
\text { Absent ankle jerks }\end{array}$ & $\begin{array}{l}73 \\
\text { Arthritis, } \\
\text { lymphadenopathy }\end{array}$ & $\begin{array}{l}\text { ESR } 28 \\
\text { IgG } 38 \text { g/1 } \\
\text { ANA } 1 / 640 \\
\text { Ro }+, \text { RF + }\end{array}$ \\
\hline $\begin{array}{l}6^{\star} \\
F(38)\end{array}$ & $\begin{array}{l}\text { Mainly autonomic } \\
\text { neuropathy }\end{array}$ & $\begin{array}{l}\text { Left tonic pupil, absent tendon } \\
\text { jerks, left sided anhidrosis }\end{array}$ & $\begin{array}{l}33 \\
\text { Left tonic pupil }\end{array}$ & $\begin{array}{l}\text { ESR } 40 \\
\text { IgG } 24 \mathrm{~g} / 1 \\
\text { RF } 1 / 64 \\
\text { ANA } 1 / 40\end{array}$ \\
\hline $\mathrm{F}^{7}(66)$ & $\begin{array}{l}\text { Autonomic } \\
\text { neuropathy }\end{array}$ & $\begin{array}{l}\text { Anhidrosis, } \\
\text { urinary incontinence }\end{array}$ & $\begin{array}{l}52 \\
\text { Fever }\end{array}$ & $\begin{array}{l}\text { ESR } 105, \text { RF } 1 / 256 \\
\text { IgG } 31 \mathrm{~g} / 1 \\
\text { IgA } 10 \cdot 2 \mathrm{~g} / 1\end{array}$ \\
\hline$\stackrel{8}{F(25)}$ & $\begin{array}{l}\text { Sensory } \\
\text { neuronopathy }\end{array}$ & $\begin{array}{l}\text { Pseudoathetosis, ataxia, loss of } \\
\text { deep sensation in all limbs, } \\
\text { diffuse areflexia }\end{array}$ & $\begin{array}{l}23 \\
\text { Hand formication, } \\
\text { imbalance, arthritis }\end{array}$ & $\begin{array}{l}\text { IgG } 22 \cdot 7 \mathrm{~g} / 1 \\
\text { C4 } 4=0 \cdot 12 \mathrm{~g} / 1 \\
\text { ANA } 1 / 640 \\
\text { RF } 1 / 128, \text { Ro }+\end{array}$ \\
\hline$\stackrel{9}{F(67)}$ & $\begin{array}{l}\text { Sensory } \\
\text { neuronopathy }\end{array}$ & $\begin{array}{l}\text { Left pseudoathetosis. } \\
\text { Asymmetric loss of deep sense } \\
\text { mainly in the arms, absent } \\
\text { ankle jerks }\end{array}$ & $\begin{array}{l}66 \\
\text { Dysaesthesia and } \\
\text { incoordination of } \\
\text { the left hand }\end{array}$ & $\begin{array}{l}\text { IgG } 21.70 \mathrm{~g} / 1 \\
\text { Ro }+, \text { antismooth muscle } \\
\text { and antithyroid } a b+\end{array}$ \\
\hline $\begin{array}{l}10 \\
F(46)\end{array}$ & $\begin{array}{l}\text { Multiple } \\
\text { mononeuropathy }\end{array}$ & $\begin{array}{l}\text { Formication and sensory loss } \\
\text { in the arms }\end{array}$ & $\begin{array}{l}40 \\
\text { Raynaud's }\end{array}$ & $\begin{array}{l}\text { ANA } 1 / 640 \\
\text { antithyroid ab + }\end{array}$ \\
\hline
\end{tabular}

*Previously reported patients ( 1 ref 2, 6 ref 7); ab = antibody; ESR = erythrocyte sedimentation rate; RF = rheumatoid factor; ANA = antinuclear ab; IoG = immunogrobulin; $M C V=$ motor conduction velocity; SCV = sensory conduction velocity; SAP = ANA = antinuclear ab; IgG = immunoglobulin; $M C V=$ motor conduction velocity; $\mathrm{SCV}=$ sensory conduction velocity; $\mathrm{SAP}=$ sensory action potential; SEF
fibre density $>7000 / \mathrm{mm}^{2}$.

patients with symmetric polyneuropathy and two with sensory neuronopathy), according to previously reported methods. ${ }^{17}$

\section{Results}

Ten patients (nine women, one man) out of 46 had clinical and neurophysiological evidence of peripheral neuropathy (21.7\%), including two patients previously described as case reports. ${ }^{27}$ One patient had multiple mononeuropathy, seven patients had distal symmetric polyneuropathy with mainly sensory or autonomic features, and two patients had sensory neuronopathy, as confirmed by neurophysiological investigation (see later), with ataxia and pseudoathetosis predominantly in the arms (table). Peripheral neuropathy was the presenting manifestation in five patients $(10.9 \%)$, being the most common onset of the disease in neuropathic patients $(50 \%)$, followed by sicca syndrome ( $30 \%)$, which was, conversely, the most common manifestation at onset in non-neuropathic patients $(55 \cdot 5 \%)$.

A comparison of the 10 patients with peripheral neuropathy and the remaining 36 without did not show any significant difference in clinical and laboratory variables. The median age was 56 (range 26-76) years in non-neuropathic patients and 66 (range 25-76) years in neuropathic patients, and median age at onset was, respectively, 47.5 (range 25-76) years and 56 (range, 23 to 73) years. The occurrence of systemic involvement was similar in the two groups, arthritis, lymphadenopathy, and interstitial pulmonary fibrosis being the most common manifestations (respectively $50 \%, 33.3 \%$, and $11.1 \%$ in non-neuropathic, and $60 \%, 50 \%$, and $10 \%$ in neuropathic patients). Segregating seven patients with distal symmetric polyneuropathy, onset of the disease after 50 years was significantly more frequent in this group (six of seven) than in non-neuropathic patients with Sjögren's syndrome ( 14 of $36 ; p=0.034$ ).

Neurophysiological study (table) showed variable abnormalities usually suggesting axonopathy in patients with distal symmetric polyneuropathy. Sympathetic skin response was absent in the two patients with autonomic neuropathy. Absent peripheral and central evoked responses in the upper extremities coupled with preserved motor responses 


\begin{tabular}{|c|c|c|c|}
\hline $\begin{array}{l}\text { Lip } \\
\text { biopsy }\end{array}$ & $\begin{array}{l}\text { Neurophysiological } \\
\text { study }\end{array}$ & $\begin{array}{l}\text { Nerve biopsy } \\
\text { fibre density }\end{array}$ & Treatment (course duration) \\
\hline+++ & $\begin{array}{l}\text { Marked denervation } \\
\text { Peroneal nerve } \mathrm{MCV} \\
27 \mathrm{~m} / \mathrm{s}\end{array}$ & $\begin{array}{l}\text { Axonal degeneration } \\
\text { with poor regeneration, } \\
\text { diffuse fibre loss } \\
2379 / \mathrm{mm}^{2}\end{array}$ & $\begin{array}{l}\text { Prednisone. } \\
\text { Slight improvement } \\
\text { (14 months) }\end{array}$ \\
\hline+ & $\begin{array}{l}\text { Moderate denervation. } \\
\text { Peroneal nerve MCV } \\
\quad 40 \mathrm{~m} / \mathrm{s} \\
\text { Sural nerve SCV } 29 \mathrm{~m} / \mathrm{s}\end{array}$ & $\begin{array}{l}\text { Remyelination, clusters } \\
7691 / \mathrm{mm}^{2}\end{array}$ & $\begin{array}{l}\text { Deflazacort, } \\
\text { hydroxychloroquine. } \\
\text { Stabilisation ( } 3 \text { months) }\end{array}$ \\
\hline+++ & $\begin{array}{l}\text { Moderate denervation. } \\
\text { Sural nerve SAP } 4 \mu \mathrm{V} \\
\text { SCV } 35 \mathrm{~m} / \mathrm{s} \text { (borderline) }\end{array}$ & $\begin{array}{l}\text { Remyelination, } \\
\text { pronounced cluster } \\
\text { formation } 5740 / \mathrm{mm}^{2}\end{array}$ & $\begin{array}{l}\text { Spontaneous stabilisation } \\
\text { (72 months) }\end{array}$ \\
\hline++ & $\begin{array}{l}\text { Mild denervation. } \\
\text { Sural nerve SAP } 5 \mu \mathrm{V}\end{array}$ & $\begin{array}{c}\text { Remyelination, sparse } \\
\text { clusters } 5692 / \mathrm{mm}^{2}\end{array}$ & $\begin{array}{l}\text { Prednisone. } \\
\text { Stabilisation ( } 96 \text { months) }\end{array}$ \\
\hline++ & $\begin{array}{l}\text { Mild denervation. } \\
\text { Sural nerve SAP } 5 \mu \mathrm{V} \\
\text { SCV } 31.6 \mathrm{~m} / \mathrm{s}\end{array}$ & Not done. & $\begin{array}{l}\text { Methylprednisolone, } \\
\text { hydroxychloroquine. } \\
\text { Progression (30 months) }\end{array}$ \\
\hline+++ & $\begin{array}{l}\text { Mild denervation. } \\
\text { Sural nerve SCV } \\
30.6 \mathrm{~m} / \mathrm{s} \text {. } \\
\text { Median SAP } 4.5 \mu \mathrm{V} \text {. } \\
\text { Absent sympathetic skin } \\
\text { response }\end{array}$ & $\begin{array}{l}\text { Remyelination, clusters. } \\
\text { Large fibre decrease } \\
6830 / \mathrm{mm}^{2}\end{array}$ & $\begin{array}{l}\text { Spontaneous stabilisation. } \\
(60 \text { months })\end{array}$ \\
\hline++ & $\begin{array}{l}\text { Normal MCV, SCV, } \\
\text { and SAP. } \\
\text { Absent sympathetic skin } \\
\text { response }\end{array}$ & Not done. & $\begin{array}{l}\text { Chlorambucil. } \\
\text { Stabilisation ( } 36 \text { months) }\end{array}$ \\
\hline+++ & $\begin{array}{l}\text { Absent SAPs in all limbs. } \\
\text { Absent SEPs in the arms. } \\
\text { Normal MCV }\end{array}$ & $\begin{array}{l}\text { Large fibre loss }(1 \cdot 2 \%), \\
\text { mononuclear } \\
\text { perivascular infiltrates } \\
5141 / \mathrm{mm}^{2}\end{array}$ & $\begin{array}{l}\text { Prednisone, azathioprine. } \\
\text { Stabilisation ( } 30 \text { months) }\end{array}$ \\
\hline+++ & $\begin{array}{l}\text { Absent SAPs and SEP in } \\
\text { the left upper limb, } \\
\text { reduced in the right, } \\
\text { mildly abnormal in the } \\
\text { legs }\end{array}$ & $\begin{array}{l}\text { Large fibre decrease } \\
(9 \cdot 6 \%) 3366 / \mathrm{m}^{2}\end{array}$ & $\begin{array}{l}\text { Prednisone, pulsed } \\
\text { cyclophosphamide. } \\
\text { Slight improvement ( } 36 \\
\text { months) }\end{array}$ \\
\hline+ & $\begin{array}{l}\text { Right median nerve SCV } \\
35 \mathrm{~m} / \mathrm{s} \\
\text { Right ulnar nerve SCV } \\
35 \mathrm{~m} / \mathrm{s} \\
\text { Left ulnar nerve SCV } \\
37 \mathrm{~m} / \mathrm{s}\end{array}$ & Not done & $\begin{array}{l}\text { Methylprednisolone. } \\
\text { Stabilisation (12 months) }\end{array}$ \\
\hline
\end{tabular}

were seen in cases 8 and 9, consistent with sensory neuronopathy. ${ }^{6}$

Nerve biopsy (table) showed moderate changes consisting of thinly myelinated fibres isolated or in clusters suggesting remyelination and regeneration, in patients with symmetric polyneuropathy (except in case 1 who showed active axonal degeneration and severe fibre loss with poor regeneration). In no case was there multifocal fibre loss. In one patient with sensory neuronopathy (case 8) there was complete loss of large fibres and intense perivascular inflammatory infiltrates, whereas in the other (case 9) there were only non-specific alterations, probably reflecting milder involvement of the lower limbs. Electron microscopy showed prominent alterations of the endoneurial microvessels, with thickening and reduplication of the basal laminae in all patients. Necrotising vasculitis was not seen.

\section{Discussion}

We found a prevalence of 21.7 of peripheral neuropathy in primary Sjögren's syndrome, similar to other studies. ${ }^{411}$ Hietaharju et al ${ }^{13}$ reported an involvement of the peripheral nervous system in 18 of 48 patients, which was, however, in the form of entrapment neuropathy or radiculopathy in most cases. A higher prevalence of $50 \%$ was reported by Andonopoulos et al $^{12}$ on the basis of neurophysiological studies, including asymptomatic patients with prolonged motor nerve terminal latency of uncertain relevance as the only abnormality; also, several patients had cryoglobulinaemia, which represents an additional important factor for the development of peripheral neuropathy. ${ }^{15}$ In our study, patients with peripheral neuropathy seemed to represent a quite definite subset of Sjögren's syndrome, in that neurological involvement was often the presenting manifestation and the main feature of the disease, whereas onset with sicca syndrome was definitely less common than in other patients with Sjögren's syndrome.

In accord with Kaplan et al ${ }^{10}$ we considered three main forms of peripheral neuropathy in Sjögren's syndrome, possibly reflecting different pathogenic mechanisms.

(1) Mononeuropathy (multiplex) was under-represented in our series, and none of our patients had a cranial neuropathy as often reported in Sjögren's syndrome, especially in the form of trigeminal neuropathy. ${ }^{1}$ As trigeminal neuropathy and mononeuropathy multiplex are a known accompaniment of other connective tissue diseases and systemic vasculitis, it is possible that their low incidence in our series was a consequence of the use of restrictive inclusion criteria.

(2) Sensory neuronopathy is a highly distinctive entity probably related to lymphocytic infiltration in the dorsal roots and ganglia. ${ }^{6918}$ In our two patients, as in most previously reported cases, 69101920 it was the presenting manifestation of Sjögren's syndrome, and was associated with especially intense infiltration on lip biopsy, and presence of perivascular inflammatory cells, but not necrotising vasculitis, in sural nerve biopsies.

(3) Distal symmetric polyneuropathy includes patients with distal sensory, sensorimotor, and autonomic polyneuropathies, assuming that these forms represent the ends of a continuum rather than distinct entities. In none of our patients did the sural nerve biopsy show necrotising vasculitis of the epineurial arterioles, whereas alterations of the endoneurial small vessels were often seen. Mellgren et $a^{8}$ suggested that symmetric polyneuropathy in Sjögren's syndrome could be related to necrotising vasculitis, but in some of their patients there were associated pathogenic factors not directly related to Sjögren's syndrome, such as systemic vasculitis, cutaneous vasculitis and cryoglobulinaemia, and association of myeloma and lymphoma. Indeed, they found evidence of necrotising vasculitis in only two of 11 nerve biopsies, whereas in the other patients there were non-diagnostic aspects of perivascular inflammation. We and others ${ }^{9}$ found similar aspects in patients with sensory neuronopathy in whom nerve fibre degeneration was likely 
caused by damage to the dorsal root ganglia rather than by peripheral nerve ischaemia. In our study, patients of this group developed Sjögren's syndrome at a significantly older age than patients without neuropathy. Aging seems to be a critical factor for polyneuropathy in Sjögren's syndrome, possibly favouring microangiopathic changes in the endoneurial vessels.

1 Kaltreider HB, Talal N. The neuropathy of Sjögren's syndrome: trigeminal nerve involvement. Ann Intern Med 1969;70:751-62.

2 Marbini A, Gemignani F, Manganelli P, Govoni E, Bragaglia MM, Ambanelli U. Hypertrophic neuropathy in Sjögren's syndrome. Acta Neuropathol 1982;87: 309-12.

3 Peyronnard J-M, Charron L, Beaudet F, Couture F. Vasculitic neuropathy in rheumatoid disease and Sjögren syndrome. Neurology 1982;32:839-45.

4 Alexander EL Arnett FC, Provost TT, Stevens MB Sjögren's syndrome: association of anti-Ro (SS-A) antibodies with vasculitis, hematologic abnormalities, and serologic hyperreactivity. Ann Intern Med 1983;98: 155-9.

5 Kennett RP, Harding AE. Peripheral neuropathy associated with the sicca syndrome. $f$ Neurol Neurosurg Psychiatry 1986;49:90-2.

6 Malinow K, Yannakakis GD, Glusman SM, et al. Subacute sensory neuronopathy secondary to dorsal root ganglionitis in primary Sjögren's syndrome. Ann Neurol 1986;20:535-7.

7 Gemignani F, Manganelli P, Pavesi G, Marbini A. Polyneuropathy in Sjögren's syndrome. A case of prevalently autonomic neuropathy with tonic pupil and prevalently autonomic neuropathy with tonic
hypohidrosis. Funct Neurol 1988;3:337-48.

8 Mellgren SI, Conn DL, Stevens JC, Dyck PJ. Peripheral neuropathy in primary Sjögren's syndrome. Neurology 1989;39:390-4
9 Griffin JW, Cornblath DR, Alexander E, C et al. Ataxic sensory neuropathy and dorsal root ganglionitis associated with Sjögren's syndrome. Ann Neurol 1990:27: 304-15.

10 Kaplan JG, Rosenberg R, Reinitz E, Buchbinder S, Schaumburg HH. Peripheral neuropathy in Sjögren's syndrome. Muscle Nerve 1990;13:570-9.

11 Binder A, Snaith ML, Isenberg D. Sjögren's syndrome: a study of its neurological complications. Br $¥$ Rheumatol study of its neuro

12 Andonopoulos AP, Lagos G, Drosos AA, Moutsopoulos HM. The spectrum of neurological involvement in Sjögren's syndrome. Br $\mathcal{f}$ Rheumatol 1990;29:21-3.

13 Hietaharju A, Jäntti V, Korpela M, Frey $H$. Nervous system involvement in systemic lupus erythematosus, Sjögren's syndrome and scleroderma. Acta Neurol Scand 1993;88:299-308.

14 Manthorpe R, Oxholm P, Prause JU, Schiødt M. The Copenhagen criteria for Sjögren's syndrome. Scand $\mathcal{F}$ Rheumatol 1986;suppl 61:19-21.

15 Gemignani F, Pavesi G, Fiocchi A, Manganelli P, Ferraccioli G, Marbini A. Peripheral neuropathy in essential mixed cryoglobulinaemia. $\mathcal{F}$ Neurol Neurosurg Psychiatry 1992;55:116-20.

16 Greenspan IS, Path MRC, Daniels TE, Talal N, Sylvester RA. The histopathology of Sjögren's syndrome in labial RA. The histopathology of Sjögren's syndrome in labial salivary gland biopsi

17 Gemignani F, Guidetti D, Bizzi P, Preda P, Cenacchi G, Marbini A. Peroneal muscular atrophy with hereditary spastic paraparesis (HMSN V) is pathologically heterogeneous. Acta Neuropathol (Berl) 1992;83: 196-201.

18 Sobue G, Yasuda T, Kachi T, Sakakibara T, Mitsuma T. Chronic progressive sensory ataxic neuropathy: clinicopathological features of idiopathic and Siögren's syndrome-associated cases. I Neurol 1993;240:1-7.

19 Graus F, Pou A, Kanterewicz E, Anderson NE. Sensory neuronopathy and Sjögren's syndrome: clinical and immunologic study of two patients. Neurology 1988;38: 1637-9.

20 Kumazawa $K$, Sobue $G$, Yamamoto $K$, Mitsuma $T$. Segmental anhidrosis in the spinal dermatomes in Segmental anhidrosis in the spinal dermatomes in
Sjögren's syndrome-associated neuropathy. Neurology
$1993 ; 43: 1820-3$. 